\title{
OF CRACKS AND CRACKDOWNS: FIVE TRANSLATIONS OF RECENT INTERNET POSTINGS
}

\section{Jesse Randall}

"The regime is apparently aware that the propaganda it has used all this time is no longer effective. We all know that the film Pemberontakan G30S/PKI [The G30S/PKI Rebellion] that is shown annually each 30 September is an object of ridicule for the kids... Things like this happen only in authoritarian countries, where truth lies solely in the hands of the rulers." 1

So remarked Ismael, head of the Yogyakarta branch of the People's Democratic Party (PRD), still "in hiding" two months after the events of July 27 became the pretext for a government crackdown against the opposition and his party. ${ }^{2}$ In this statement, Ismael was responding to the military's efforts to lecture junior high school students about the "latent danger" of communism and the PRD. ${ }^{3}$ Ismael asked Udin, a junior high (SMP) student, if he could remember anything interesting that was said by

\footnotetext{
1 PRD release, No: 01096/4/10/PRDInt/Jn/art-int

2 The situation in Jakarta was tense in July after it became clear that the government would not suffer Megawati Sukarnoputri to remain part of the leadership of the PDI [Indonesia Democratic Party]. After a rump PDI congress in Medan installed Soerjadi as chair, the PDI was split. Megawati and her supporters held the PDI headquarters in Jakarta, sponsoring open-mike speak-outs throughout July. On July 27, socalled Soerjadi supporters, probably some combination of soldiers and thugs, invaded the PDI headquarters, sparking massive riots in Jakarta. The PRD [People's Democratic Party], which had supported Megawati's PDI, became the primary scapegoat.

${ }^{3}$ As of early October, thirty-four PRD members were to be tried under the Anti-Subversion Laws although, a recent "Update on the PRD Case" reports, "the wrongdoing has been changed from 'conspiring for a coup d'etat' to 'being a communist organization and spreading communist propaganda."'
} 
the soldier. He answered: "Nothing. Because everything he said I hear all the time from my teachers and read in the school books."

In some respects, the most significant outcome of this recent crackdown is not that the opposition has been temporarily cowed into quiescence, but that the standard red scare tactics normally more than sufficient to justify such swift repression have this time been, with scant exception, universally recognized as absurd. The cracks in the New Order's ideological foundation now seem beyond cosmetic repair.

Nowhere is this more apparent than on the Internet. It is not necessary to exaggerate the democratic potential of the Net to recognize that it has created an open forum for the expression of ideas in print of a kind not available to Indonesians for some decades, underground leaflets aside. The timing also helped, since even half a year ago Internet subscriptions in Indonesia had not yet surged to the level that they had by July, and half a year from now it is likely that the government will have at least made efforts to follow Singapore's lead in restricting Internet content.

It is also noteworthy that in a medium necessarily dominated by, if not to say limited to, an elite with access to computers and modems, reactions to government violence against its political opposition ranged from displeased to outraged. Although it is true that established critics of the regime, including the PRD itself, lead in the production of information distributed over mailing lists such as "Apakabar's" Indonesia$\mathrm{L}$ and Pijar's "KdP Net," the fact that no more than a handful of readers publicly complained of excessive criticism indicates, given the potential political return to public expressions of allegiance, that the rest found these reports and commentaries entirely plausible.

More startling still were the crude terms in which expressions of disgust were being put, and not only by the career critics. Writing under pseudonyms and from their private e-mail accounts, several Indonesian posters expressed a revulsion at the reaction of the authorities that seemed to come from being confronted suddenly and for the first time with a vicious side of the military generally unseen in Jakarta.

In light of these developments, we offer here the following five translations of items posted on the Internet preceding or following the July 27 riots and subsequent crackdown. Though they are not intended to be strictly representative, they were selected because they are good examples of declarations that reveal the degree to which official representations of the events have failed to dominate. The first, "ABRI is the Subversive One," contributed under the pseudonym "bullshitter" and actually posted a week before the raid on the PDI headquarters, is one of these anonymous tirades. In the second, a member of Pijar (also writing under a pseudonym) issues a warning to those in power that their time will come. The third, composed by Goenawan Mohamad, also written before the raid, was posted as a critique of Media Indonesia, a newspaper that not only agreed to "censor" its own reports of the opposition's resistance efforts, but also called on other newspapers to maintain a "prudent attitude" in response to the outspokenness of Megawati's PDI. The fourth, written by someone who identifies herself as a normal member of the PRD, asserts that Pancasila and the 1945 Constitution have become no more than a shield for hypocrites and despots. Lastly, Father Mangunwijaya's piece, which urges compassion for the "kids" in the PRD who 
are being hunted down, submitted to and rejected by the Indonesian press, found expression only over the Internet. ${ }^{4}$

\section{$A B R I$ is the Subversive One}

Our $\mathrm{ABRI}^{5}$ is kind of bizarre. If the PDI is split in pieces they say it's for national unity, but if the people protest in the streets they call it disturbing security, subversion, anti-Pancasila, PKI tactics, as if they're blind to what causes people to take to the streets. The subversive one is none other than ABRI itself. It looks like our state elites are all totally out of their minds and their statements are worse than revolting. But all right, we can't blame ABRI in its entirety because perhaps there are those in the rank and file who aren't all that against the people, only those at the top who were directly appointed by Suharto, and who, nota bene, were all Suharto's former bodyguards who will defend his private kingdom to the death. Unmistakably, Suharto is beginning to feel that the awareness of the people is getting more and more dangerous now that they've been fucked over by him for 30 years, so he's prodded the ex-Cendana guard dogs to make sure that his riches aren't lost due to any conflict. It's no secret in elite circles that Hartono is "used" by Miss Tutut,, so no wonder he says that ABRI has to listen to her orders. Good God, where the hell are these people taking this country? It's time for the people to campaign directly to ABRI itself to make the rank and file realize that what their superiors are doing is totally off the wall and anti-Pancasila, so if necessary we should split ABRI using the same tactics that split the PDI. These people obviously don't want Suharto to step down because they'll lose their silver spoons. ${ }^{7}$ It looks like this time Yogie S. M. (Systematic Mistakes) really made his fatal mistake. ${ }^{8}$ But Suharto is still the shrewdest of them all; before the "congress" gave Yogie the goahead to go to Medan, after support for Megawati peaked, he refused to meet Surjadi. In the end it was Yogie and Akbar Tanjung who took the fall. After they've retired, their memoirs will curse Suharto's unbelievable cunning. I just want to know what they hell these people pray for each night...

Just picture all these utterly bizarre things: the Palace Son-in-Law is promoted $2 x$ in one year, Ilham Habibie rises through the ranks like a helicopter made by his dad, Iqbar Habibie becomes the head of the jet project at IPTN (if he needs funds all his "old man" has to do is sign), BPPC money vaporized, the Timor national car, the case

${ }^{4}$ When possible, the editors solicited and received permission to "reprint" these postings. We have also been informed by the facilitator of Indonesia- $\mathrm{L}$ that "All who sign up for the list must agree that their postings may be re-posted without asking permission, unless this is otherwise stated in the posting."

${ }^{5}$ The Armed Forces of the Republic of Indonesia, construed as singular.

6 dipakai, more than "used" in English, suggests used for sex.

7 "... sebab piring emasnya juga akan hilang." Literally, they'd lose their "gold plates."

${ }^{8}$ What the author has as "Yogie S. M. (Salah Melulu)," or "continuous mistakes," rendered here as

"Systematic Mistakes" to retain the plesetan-the pun-on the interior minister's initials. 
of the Supreme Court, the case of Eddy Tansil, Extasy port authority Arie Sigit. ${ }^{9}$ Unfortunately, our sole king has never been aware of his own greed. Otherwise, Suharto has got to be the most infamous damn name in all of the history of Indonesia. All of his great service in the field of politics, economics, etc. will come to nothing because of his greed. You've got to understand that according to a trusted source, when Indonesia was granted the ranking as the second most corrupt state, Murdiono and Suharto were totally pissed because they didn't win first place ...

Surely the only solution is revolution, trading fresh blood for true healing from this destruction.

Peace,

"a bullshitter"10

\section{It's Only a Matter of Time ... (The People are Fed-Up) by PranaCitra ${ }^{11}$}

Violence and rioting have returned. "In times like these, it's only a matter of time," said a friend. On Saturday July 27, 1996, the majority of the people in the capital joined in witnessing the shredding of the veil of a "political stability" which for dozens of years has been deified by the New Order government. The PDI headquarters was attacked and taken by force, and the people are fed-up. Jakarta is full of blood.

Appearances. As it turns out, the stability which has been erected upon the foundation of efforts to terrify the people is like a dam holding back a flood which gets swifter by the second. It is only a matter of time, as we know, before drops of water

9 The "Palace Son-in-Law" is Prabowo, son-in-law of Suharto. Ilham Habibie and Iqbar Habibie are sons of Baharuddin Jusuf Habibie, State Minister for Research and Technology, President-Director of IPTN [Industri Pesawat Terbang Nusantara], the state's aircraft production agency. BPPC [Badan Pengembangan Pengelolaan dan Pemasaran Cengkeh] is the Clove Support and Trading Board, which has been widely criticized by farmers and local traders as a mismanaged, monopolistic agency that benefits private spice traders in alliance with its chairman, Tommy, the youngest son of Suharto. "Timor" is the brand name of a car presented as a national product, which is in fact produced as the result of a joint venture between the Korean car company, Hyundai, and Suharto's son, Tommy; other automobile companies have protested the arrangement because the Timor company receives tax breaks that substantially reduce the prices of their automobiles. Eddy Tansil is a Chinese businessman (the protégé of Retired Admiral Soedomo) who escaped from prison following his conviction as a result of financial scandals. Arie Sigit is grandson to Suharto, reportedly one of Jakarta's most successful dealers in the drug, Extasy.

10 the poster signs "wasalam, tukang ngoceh"

11 Pranacitra is a tragic Javanese love story set in the Mataram Kingdom during the reign of the Sultan Agun. One of the Sultan's older, victorious commanders had been keeping the young woman, Rara Mendut, to become his mistress, but she met and fell in love with Pranacitra, who was subsequently killed by the enraged commander. Rara Mendut then killed herself with the same kris that had been used to kill her lover. 
cut a hole in stone. A brittle dam, facing popular anger which for decades has been held back but has never receded, is insignificant.

For years upon years, the answer is always the same when the people demand their rights: For Development. No protest, surely enforced by the gun. When the intelligentsia criticize this unjust development model, they are immediately braced to lose their jobs. When the parliament does its duty, recall is the result. ${ }^{12}$ If a businessman succeeds in his enterprise, children of state officials are waiting to snatch it up, the bureaucracy squeezes him, and holier-than-thou officials ask for a cut. If the press expresses honesty and facts, it is consequently banned.

If the people think they shouldn't give up under the circumstances and decide to fight for change and for political and economic reform, the door of the prison stands in their way, right before their eyes. Always defeated, but who is able to extinguish these innocent demands which constantly rage? Sometimes, maybe, they will be mixed up with anger as with normal human beings. But they will nevertheless always be there. The history of human struggle is clear proof of this.

Likewise too with the demand for democracy. It is pointless to scapegoat it. It is pointless to look for a "third party." It is pointless to try to fool the people, as if they have no need to inhale democracy. Democracy is like the air, though the common people perhaps can't pronounce the name. But they feel it, they need it. If you close all the doors and windows of this country until the air thins, we will have to all shout together, "we need to breathe, we need air." We need democracy, or we will be furious.

Now the people are past anger. Maybe it will quickly subside, maybe not. But one thing is certain, as long as they aren't given any air, they will continue to be angry. It is only a matter of time.

It is pointless, oh Rulers, you accuse, you transfer the blame and search for scapegoats- "Disrupting stability," "the methods of the PKI," "there's a third party," what else?-as long as you don't pull out the roots of the problem, you will never truly solve the problem. You will never sleep soundly at night. Perhaps you can stand guard with your weapons. But these weapons which are actually a shield from your fears will never put you at ease for your entire life. There is no certainty that the shining blood under the feet of your power, the screams of suffering under your possessions, cannot still disturb your tranquility. How long will you hold out guarding them? Until the horror of the gates of death is right in front of your eyes? It is only a matter of time.

The Stability which you have built, once again, is an illusion. True stability is not built before the barrel of the gun. It requires participation, active involvement of the people in it. And the people will only be involved when there is justice, prosperity, and democracy. Realize this, because you will not be in power forever.

Once again, it is only a matter of time.

12 Parliamentarians can be recalled from their positions if they stray too far from the party line. Most notably, this happened in 1995 to Sri Bintang Pamungkas, formerly of the PPP (United Development Party, the Islamic party). 


\section{Open Letter to Media Indonesia From Goenawan Mohamad}

Dear Surya Paloh and friends at Media Indonesia,

I understand how difficult it is to face the choice between being banned and keeping your mouth shut. I appreciate fear, including the fear you all must feel. As a former editor-in-chief, I have also experienced it. I am also no hero.

I have said, and allow me to repeat it here, that editing a magazine or a newspaper in Indonesia can be likened to flying a hijacked passenger plane. The pilot is forced to land wherever the hijackers want, and if he resists or even appears obstinate, the plane will be blown up by remote control. All of the passengers and crew will suffer this disaster, while the hijackers will be safe and sound: the sky looks clear, they will say.

For years upon years the situation has gone on like this in this country. It has been the norm for so long that this terror has been internalized into our entire system of thought. Even the pilot begins not to be aware that there is something despicable about the situation. The pilot hasn't just surrendered. He has been defiled. The hijacker knows full well the fear of the victims and perhaps laughs contentedly to himself in his room. And his laugh grows all the more piercing, because he knows that this fear which spreads like cancer has ultimately caused others to submit.

Submit, because we victims begin to think, and moreover to articulate, that this intimidation is just and right and that we are the guilty ones rather than the ones being mugged.

Submit, because whenever a newspaper or magazine is banned, the chief editors and reporters of the others are not only silent, but they fault those whose paper was shut down. This capitulation will have attained perfection when an editor-in-chief of a finished-off paper begins to fault himself or fault his co-workers. In other words, we no longer have any mental capacity to ward off that which is actually unjust.

It is at that moment that something tragic happens. In the end we all feel that it is we (the ones being threatened with the bomb) who aspire to do terrible things, while the hijackers are the noble and just saviors. We admire them, we side with them, we love them. We have been afflicted with the Winston syndrome-from the character Winston Smith, in George Orwell's novel, 1984-who is arrested and constantly interrogated and in the end begins to love the power that so treats him. 
This actually means that we have lost our self-respect. We are annihilated as human beings, we are finished as citizens, particularly as taxpayers-although we know that with the money earned through our hard labor we have funded the lifestyles of these muzzlers behind the desks of bureaucracy.

Through my experience over the years, in the end I realized that I needed a strategy against the insanity of this anomaly. I think we can all do the same thing, without being heroes, by beginning to say to ourselves: No, this situation is not just. I respect fear, because fear can sometimes save lives, as long as we don't start to further humiliate ourselves.

My good friends, you have decided not to print news about the PDI, this persecuted party, for a month. I have heard that the threat of being banned is so close that the sword is just inches from your neck. But let's make one thing clear: powerlessness under threat is one thing. Submission is another.

In my view, and pardon these words, you have already submitted. Worse still: You have so thoroughly submitted that you are complicit in compromising lies, even though I know this was not your intent.

The first lie is that in our great nation there are no angry people-who are ready to die or be jailed-due to their wounded sense of justice, because there is a small political party which is about to be eliminated without the smallest regard for the most elementary ethics.

The second lie is that the first lie is something born of nobility of the spirit and a patriotic attitude. On the front page of Media Indonesia you call upon the rest of the media to censor themselves as you have censored yourself. In large print over the red and white, you mention the need for prudent attitude.

Friends, let us not lower the red and white so far down that it touches the filthy ground. Let us not make the symbol of bravery-in-truth into the sign of our confusion. Far too many people are talking about a patriotic spirit and this sanctions oppression. We have been dragged so far from our memories, that colonialism at its base is a system that produces a colony of slaves living in fear, that it was colonialism which introduced regulations on banning the press, which eliminated political organizations, and which stomped down the spirit of uprising. August approaches. Let us remember when we first craved freedom, because we know that freedom is a matter of rights and responsibilities.

As human beings and as citizens of a Republic we have a right to freedom. As journalists we have a responsibility to freedom. We cannot, and may not, allow freedom to die. Because we know, and allow me to paraphrase Camus, that freedom never dies alone. At the same moment, justice will be gone forever, our people will begin to protest, and the innocent ones will be persecuted daily.

Friends. Almost every night I go by the PDI office which has become a kind of symbol of struggle. Almost every night I hear the voices of the youth who feel there is much to be done, with body, thought, and spirit, so that no more innocents will be persecuted. From them I found something which is difficult to find now, namely the hope for a better Republic. But in your voices I find only sadness. I am sad that you have to censor yourselves, and although you intended to cover both quarreling parties, 
in the end that is not what you did-chiefly because one of the parties has power over you while the other one only has self-respect and a willingness to sacrifice which perhaps doesn't mean much to you.

But I am even more saddened because you, with lofty excuses, have called upon the rest of the media to censor themselves as you have done, and thus have complicated their position: because if other media do not do as you have done, they will appear unwilling to sacrifice and disloyal to their country. Perhaps you want togetherness. However, in a profession in which defending integrity has become a lonely duty, let us come together not in a conspiracy of silence, but in an effort to give hope to the unheard and to hear those without hope.

July 29, 1996

\section{The People Will Fight On!}

The people's resistance against the injustice, poverty, and all forms of oppression that have coiled around the people's neck for so long is taking form as the objective conditions become all the more determinate-that is, stepped-up efforts to steal the people's land, a labor system ever more beyond repair, an increasingly dysfunctional judicial system, the shackling of freedom of the press, a coarser and more greedy political system which destroys democracy, ever more clear and obvious corruption as a consequence of collusion between bureaucrats and holders of capital, and an increasingly repressive apparatus of power that oppresses the people in order to protect the 'stability' necessary to exploit all resources.

Only hypocrisy, loyal to its own interests, can get away with constantly turning a blind eye and twisting the facts in front of hundreds of millions of the people who are aware of and revolted by the empty propaganda. No matter how hard you try to cover up a rotting stench, it can surely still be smelled. Moreover, these hypocrites will be forced to swallow all the rot that they themselves have created. Because no matter what they say, the people are not stupid ${ }^{13}$ and will surely prevail in exposing all the crimes and filth which have long become a chronic disease due to this system loyal to greedy power.

$[\ldots]$

Actually the democratic movement led by the PRD hopes for a transfer of power and change through the path of peace. The extra-parliamentary and parliamentary struggle follows the examples of peoples' struggles in other democratic countries, like Sri Lanka, Bangladesh, India, Korea, Thailand, and the Philippines. Where the people can constitutionally organize, form parties, and determine their own aspirations, such

13 rakyat tidak bodoh, a departure from the standard elite view, rakyat masih bodoh, which does not quite mean that the people are still stupid. 
as for change and a transfer of power in order to guarantee the continuation of justice and democracy in a country which belongs to the people. This is even in the preamble to the 1945 Constitution and in its articles as well as in Pancasila. Of course, all this time the 1945 Constitution and Pancasila have only been instruments used to beat the people who struggle for sovereignty. Even though it is the people who try to enforce each article of the 1945 Constitution and Pancasila by way of the movement, the organizations, and the new parties which had spread before July 27. The People's Democratic Party and its mass organizations are among those who have made a consistent effort to struggle without paying lip service to the issue of the "national ideological basis," the 1945 Constitution and Pancasila, because it is now an open secret that only corrupters, hypocrites, and despotic rulers have to hide behind the 1945 Constitution and Pancasila-and make them into a mantra to plunder and oppress the people. If you look at the manifesto and the by-laws of the PRD there is not one thing that conflicts with the 1945 Constitution and Pancasila. The picture painted in the manifesto only presents conclusions based on the objective facts that stand before the masses.

The fear of the rulers toward the democratic forces mobilized by the people engendered the violence by spilling blood to occupy the PDI HQ, shackling the people with threats, and finally playing them off against each other by looking for a scapegoat. Surely had they not been struck down by ABRI maneuvers (the attack on the PDIMegawati HQ and the bomb threat), the coalition of the PDI, the PRD, and the Petition of the First of July and MARI ${ }^{14}$ would definitely have been able to lead the people in bringing about change and a transfer of power. For this coalition won wide popular support from the masses, and from all circles: labor, farmers, the urban poor, students, youth, artists, journalists, professionals, politicians, and veterans (and moreover from a number of bureaucrats and active members of $\mathrm{ABRI}$ ).

The 27 th of July is important because it opened the eyes of the people that, as it turns out, the people can indeed go on the move. ${ }^{15}$ Because the response of the people to the attack on the PDI HQ brought forth a wave of mass action that was both spontaneous and broad-based. The fires which caused the loss of hundreds of billions of rupiah were initiated by a disgusted people who have been oppressed and robbed of their rights for dozens of years. However, is it fair that we fault these angry masses who ran amuck? Even though it is the people who feel directly-skin, flesh, and bones-the meaning of oppression in the guise of New Order development and its stability? From the actions of the Maubere people (the East Timorese), and the people of Papua (West Irian), Aceh, Lampung, Tanjung Priok-and many other places-we can conclude that oppression is the cause of resistance. Because humans are not animals-we have minds and rights and self-respect for life! Even worms will squirm when trampled upon!

14 Petisi 1 Juli (Petition of the First of July) and MARI [Majelis Asosiasi Rakyat Indonesia, Federation of the Associations of the Indonesian People] were unofficial political organizations that formed when it became obvious Megawati was about to be ousted from her position as leader of the PDI. MARI is an umbrella organization established through an alliance of twenty-six NGO's, committed to mobilizing the views of the common people and pressing for more representative government.

15 bergerak, to move, in the sense of a political movement. Agency is key here: they are not merely "mobilized" and do not follow a "movement" but actually "move." 
46 Jesse Randall

$[\ldots]$

The military intervention in the PDI which led to the congress and the attack on the PDI-Megawati HQ and the violence which claimed hundreds of casualties came on the direct orders of Soeharto. So Soeharto and his elites have to take responsibility. They are the ones who will have to stand before a tribunal, on charges of deviating from the 1945 Constitution and Pancasila, the massacres of the people in 1965-1966, the massacres in Maubere (sic, East Timor), Papua, Aceh, Lampung and Tanjung Priok. It is appropriate that the people demand that Soeharto be tried. Like the two presidents of South Korea! Even the night has stars, tomorrow the sun will rise. Rise up and resist oh people of Indonesia, democracy or death!

Retno Yulianti, (regular PRD member on the field of struggle in Indonesia)

PRD

\section{YB Mangunwijaya}

The PRD is nowadays branded as whatever, orchestrator free-rider freeloader kindler agitator progenitor or progeny of the PKI and who knows what else, the point is it must be smashed. ${ }^{16}$ It turns out that I myself am a backward creature of an isolated tribe, because before the incident of last 27 July I had never heard about the existence of the PRD. Of course I have known Wiji Thukul for more than 10 years, and most recently met him on the campus green at Monash University about four years ago. He was on a poetry tour. I liked his poetry because it sang the message of the suffering of the people to which I must pay serious attention if I still want to be called a man of religion. ${ }^{17}$ So I was startled when his name was attached to the tail of the PDI Congress in Medan which so "thrillingly" competed with Atlanta. ${ }^{18}$

I am no practical politician who has any competence to evaluate whether it is true that the kids in the PRD and those affiliates which have been called its onderbouw ${ }^{19}$ are

16 "PRD kini dicap sebagai entah dalang penunggang pembonceng penyulut penghasut biang atau anak PKI entah apa lagi, pokoknya harus digebuk." Romo Mangun strings together the whole host of accusations of being "behind it all" which are now tired features of New Order discourse. Dalang is a shadow puppet master, penunggang connotes holding a horse's reins, and biang, lit. mother, most often appears as "biang keladi," a ringleader or a mastermind.

17 The word translated as "man of religion" throughout is rohaniawan, which connotes spirituality.

18 The Medan PDI Congress installed Soerjadi and ousted Megawati Soekarnoputri for the party chairmanship. "Atlanta" refers to the 1996 summer Olympics held in Atlanta, Georgia, USA.

19 "Onderbouw" is the Dutch term for subordinate organizations that branch off from a larger structure, usually a party structure. The PRD encompasses SMID [Solidaritas Mahasiswa Indonesia untuk Demokrasi], PPBI [Pusat Perjuangan Buruh Indonesia], JAKER [Jaringan Kesenian Rakyat], STN [Serikat Tani Nasional], and SPRIM [Solidaritas Perjuangan Rakyat Indonesia untuk Maubere]. These are student, labor, cultural, farmer, and East Timor solidarity groups, respectively. 
communists or not, marxists or leninists or maoists or aiditists ${ }^{20}$ or actually only normal budimanists (not Arief Budiman but Budiman Sudjatmiko, from an artistic point of view both very lovely names which make me jealous). ${ }^{21}$ I am only a normal man of religion who also normally and fittingly empathizes and sympathizes with the youth, whether the nice youth or the naughty youth it's all the same. Maybe it is because my life phase has already entered the stage of "advanced age"22 (another poetic expression, but not one to be envied) and now in this broken-down condition it is fitting to be attacked, in solidarity, by heart failure.

So this writing about the PRD is also not at all political theoretical let alone practical. And clearly without a club in my hand or tear gas in the intervals or tin or rubber bullets in the gun barrel etc. I only want to state my empathy and sympathy toward the young kids who are now accused (not yet sentenced, so we have to respect the presumption of innocence if we live in a country under the rule of law) and whose guilt is apparently only: impatience. But yah, where in this world are there young kids who are patient? Wouldn't these no longer be youths, but old fart grandpas like me here? And furthermore, if I compare today's Indonesian kawulo mudo ${ }^{23}$ with the young boys and girls of Holland Germany England, or better if compared to the young generation of Soekarno-Hatta and the Youth Pledge of yore, wah, how come they just look like a bunch of serimpi ${ }^{24}$ dancers? But patience and impatience are of course relative, and can't be measured with mathematical precision.

Anyway, the photo of Wiji Thukul in the papers clearly resembles the guy. Only you can't see that his ear hasn't yet healed properly or that his eye is even more bloody and half-blind as a result of being tortured because according to Republika (a quality paper) his head which is full of poetry was rammed unpoetically by the unpoetic body of a jeep owned by a state official (Pancasila) of course certainly by a figure beyond the accountability of the state based on the rule of law and the 1945 constitution, and whom we will never be able to hold accountable. But that is not important (although it is actually important).

The photo of Budiman Sudjatmiko in the magazine Forum Keadilan (which very oddly resembles time, although time has been banned ${ }^{25}$ ) appears gloomy, like thefuture-looks-bleak youth ${ }^{26}$, but according to the newspaper again, he is a radical youth (from the Latin root radix = roots, perhaps grassroots) who is clearly determined to

\footnotetext{
${ }^{20}$ Aidit was the leader of the PKI until he was killed in October 1965. The PKI was legally banned in March 1966.

${ }^{21}$ Budiman Sudjatmiko is the chairman of the PRD, now in detention and facing subversion charges. Arief Budiman is a prominent academic recently effectively sacked along with a number of other critical faculty members from the University of Satya Wacana in Salatiga, Central Java. The word "budiman" means wise or prudent and the name suggests someone literate or accomplished in the arts.

22 lansia, lanjut usia, more colloquially, old age.

${ }^{23} \mathrm{He}$ uses the Javanese for the current voguish (and thoroughly subjected) term for the youth, kazula muda.

24 serempi: a refined, classical court dance

25 "Tempo" rendered in lower case in the original, literally as "time," although it is the title of the banned news weekly Tempo, which was self-consciously styled after Time magazine. Forum Keadilan, another leading weekly, means Justice Forum.

${ }^{26}$ He coins hardebu, for hari depan kelabu.
} 
strive onward, no matter what. ${ }^{27}$ I've studied his face, how come he resembles the Russian underground student leader who fought the communists in the famous film Doctor Zhivago (originally based on the book by Nobel Prize for Literature winner Boris Pasternak). So it flies in the face of the accusations of the authorities. But in the photo published by the daily republika he is brighter although still too eerily serious for today's discotheque era. Different than the one standing to his left, smiling pleasantly in that oh-so Indonesian way. ${ }^{28}$ In another photo, a girl (with intellectual glasses) appears sitting at the organizers' table at the PRD founding ceremony, while at the mike is the Magsaysay prize-winner Pramoedya Ananta Toer giving a speech (from notes, perhaps so as not to slip up). Is that the girl named F. Ria Susanti, the head of the Department of International Relations of the PRD? Pretty sharp. There is also a photo of Andi Arief (hey, are the fearless ones always named Arief, Arief Rahman Hakim for example, and that one keeping his mouth shut in Salatiga? ${ }^{29}$ ) He is like a sympathetic SMU (sic, SMA?) kid who has just begun practicing basketball.

But most impressive is a big photo in this daily founded by Minister of Research and Technology B. J. Habibie, which shows a group of teens with heads bound like samurais with headbands inscribed with the letters PRD and a symbol of a star and a cogwheel. They're pointing their clenched fists upward (clenching differently than the communists usually did: their thumbs pointing to heaven, while the thumbs of communist fists pointed toward Moscow or Beijing). Whether they're screaming an aaa or an ooo can't be determined from the photo. Looking at these still young and cute teens (ndemenakake in Javanese, which means: something that makes the heart pleased and full of affection) I mumble to myself something I hope isn't overheard by anyone else: ah, you've gotta be kidding calling these funny cute kids communists! ${ }^{30}$ Communists in the general widely-held sense, not meant as the followers of the philosophy of Marx or bolshevik political theory, leninism, stalinism, maoism, or aiditism, but of brutal ruthless criminal spores of the devil who must be trampled to death by the authorities like cockroaches or shot down dazed (knocked out) like panthers. ${ }^{31}$ I don't know, I always want to be honest: looking at such ndemenakake, touching photos, how come I'm instead overcome by a feeling of empathy or sympathy toward them? Although-no matter that-even though-notwithstanding the fact that-this is totally outlawed. You have to understand that I am not a spy but a normal man of religion.

Maybe by admitting I'm too honest like this I'll be charged with being too sentimental or romantic or a dreamer or in the language of the PKI: a utopian, or if unlucky, a subversive, only because I feel a gentle but deep touch of sympathetic affection toward these ndemenakake kids, who now are certainly running helter-skelter, hidden away by their parents who knows where, in Boven Digul, Nusa Kambangan, or Pulau Buru ${ }^{32}$ or perhaps it's possible someone somewhere still has a dense forest in which to hide these kids struck by disaster (for the time being). And I feel like crying, in

27 rawe-rawe rantas malang-malang putung is a proverbial Javanese phrase that speaks of perseverence.

28 "khas ala Indonesia," literally, "unique ala Indonesia."

29 See note 5.

30 "ah mosok anak-anak lucu ndemenakake ini komunis?"

31 "tetapi penjahat buas ganas kakeknya iblis yang oleh aparat harus diinjak mampus seperti coro atau ditembak klenger (tak berkutik) seperti macan kumbang."

32 Boven Digul, Nusa Kambangan, and Palau Buru: penal colonies 
the moan of the ancestors of Java: "Duh Gusti, nyuwun kawelasan." (Lord, we beg your mercy). "Cah durung iso sisi ngono kok ya komunis ki ketemu pirang perkoro." (What kind of twisted reasoning concludes that kids like these who still can't blow their noses are communists?) But of course this is an outlawed feeling. So I officially take it back, "rather than causing a commotion," say the ancient ones.

But in my heart I send up my respect and admiration and prayers. This is actually hypocritical, because why should a feeling in one's heart be poured out in a composition for a capital city daily? But never mind, hypocritical and not hypocritical are also relative, no need to make a big fuss of it. The important thing is that these kids be protected and loved. Not pursued. We were also once teens and youths, no? And supposing they are guilty, yeah just forget it, who in these times isn't guilty? He who has never sinned may cast the first stone. Of course it is all complex. No need to add to the complexity. Communists? Leninism, Stalinism, Maoism, Aiditism? Whatever, but we should care for these accused kids, and respect them. This is the most enlightened attitude. And we should be brave enough to uphold the convictions and teachings of every grandfather who still wants to be called a normal grandfather who loves his grandchildren.

\section{The Presumption Of Innocence}

There are those who say scientifically that the PRD is a variant of revolutionary Marxism. But there are experts (Dr. Arbi Sanit, a professor at the University of Indonesia who, as a state official, is safe to be believed by even the most robotic state official) of precisely the opposite opinion: the $27 \mathrm{July}$ incident is the result of the government's political mismanagement. Maybe what he means is: a consequence of the mismanagement of running the PDI congress in Medan. For example, Irianese representatives told a dozen journalists that they were given a ticket by ... (I can't and have no need to say by whom because it is already clear) and a wad of pocket money, on the condition that they dutifully attend the PDI Congress in Medan. But in mid-course they stopped in Jakarta and joined in support of Megawati Sukarnoputri at Jalan Diponegoro, wah just like a Stambul road show or that Sawung Kampret soap opera made by Dwi Koen. ${ }^{33}$

But we have to remember that the PDI Congress in Medan has never been officially called the spark of the red fires of the 27 th of July. So officially there is no connection with the riots whose chronology (although over-detailed) was broadcast on-line over the internet by several sources (for the sake of national stability the internet should be banned).

Maybe there are patriotic anti-communist readers who will accuse this article of being full of sympathy toward the rioters and arsonists and disturbers of the peace of 27 July. I beg you not to be rash in drawing this conclusion as is the habit of the authorities. Here I officially state that I totally concur and support the statement of my friend Mohamad Sobary in Republika, a celebrity from Yogyakarta (Bantul, to be precise), who

33 Stambul road show: originally "komedi Stambul," a kind of traveling stage show that adapts stories from a range of sources, including tales from the Middle East, hence "Stambul," Istanbul. "Sawung Kampret" is a satirical comic series published in the humor magazine, "Humor Nasional." 
is renowned as a Corner columnist (but who has never cornered anyone) ${ }^{34}$ and an expert in socio-political affairs at LIPI, 35 who very much regrets the emergence of violence, which according to him need never have happened. Yes, I too feel the same way. But-how does it go-it's a snake because it comes from a snake egg. So too it seems with violence, which comes from other eggs of violence (usually a lot of them). Violence which originally started where and by whom, nah, sorry but that's off the record.

But how come there is more violence than sweet softness (sweet softness like Megawati Sukarnoputri, say the youth)? Yes, answered Mas Sobary to the Republika reporter: "Because we are in a condition in which the pattern of violence is a more obvious, bigger, more institutionalized, and more prominent feature in the structure of the social, economic, and political body. Meanwhile, refinedness, softness, peace, and an attitude of non-violence reside in the world of ideas. (or in the figure of Megawati Sukarnoputri, comment these young kids again.) $)^{36}$

"Other than that," our expert went on, "even if the movement of violence is killed it will grow back." Whoa, so what are we supposed to do? Our good Muslim ${ }^{37}$ from Bantul explained, and I emphasize, I totally agree: "Look at the situation clearly, and then support efforts to resolve the conflict peacefully. Our home is better built without violence." So look at things clearly. What he means is: objectively and honestly, it will all make itself clear. It's in accordance with the wisdom of Java but is actually universal: becik ketitik olo ketoro (the good is naturally seen and noted, while the bad is also visible even when concealed). ${ }^{38}$

So if the majority of the people of Indonesia still have a clear and pure heart (and I believe that they do), we don't have to be very worried (emphasis on "very") since soon, whether before or after the upcoming ultra-honest ${ }^{39}$ election, yang becik akan ketitik dan yang olo akan ketoro. Musing over the lofty words of Mas Sobary, I recall a cheerful song (a spontaneous reaction) of a sindhen (a traditional female vocalist) from Yogyakarta or Bantul who sings in erotic, ribald humor but in our case full of meaning: "Jeneh kowe, sing marah-marahi." (The word jeneh is very difficult to translate, but maybe this naughty sentence can be Indonesian-ized freely: "It's your own damn fault, you're the one who started it, right?") But once again, in a country under the rule of

\footnotetext{
34 the pojok (literally, corner) are short, satirical journalistic pieces, typically written under pseudonyms and meant to poke fun at officials. They are usually published in the bottom corner of a front page.

35 the Indonesian Institute of Sciences.

36 End quote not clear in the original posting.

37 Santri.

38 Though the Indonesian gloss given is rendered here, the Javanese is perhaps closer to "In the end, good deeds will be noted, bad deeds will be noticed."

${ }^{39}$ mahaluber, satirizing the acronym for the New Order election ideal, luber (lit. overflowing), langsung, umum, bebas, rahasia: direct, public, free, secret.
} 
law the presumption of innocence must be in effect before the supreme judges from the most honest institution in our land, the Supreme Court, lay down their sanctified judgment. ${ }^{40}$

\section{August 1996}

${ }^{40} \mathrm{He}$ uses berfatwa, to make a binding judgment under Islamic law, rather than memvonis, a term of Dutch origin commonly used in Indonesian jurisprudence. 
